There is no doubt that sterilised milk as a continuous diet will in time produce scurvy. It is equally clear that such a diet must be continued for many months-eight months in Case 1 and then only a very mild form of the disease; more than a vear in Case 4 and hence a more serious attack. In both these instances nothing else was given. But are we to condemn the cooking of milk for such a reason as this ? I can point to a very large number of infants who have been fed on boiled milk for many months and have never developed scurvy and have gained weight as rapidly as the most anxious mother could wish. The other two cases illustrate still more strongly the disadvantages of cooked foods, especially the prolonged cooking to which the proprietary foods are subjected in order to preserve them. Even in these instances the scurvy took many months to develop and a little modification of the diet would have prevented it entirely.

In conclusion, I most strongly maintain that the boiling of milk for infants is essential, save under most exceptional surroundings ; that the longer milk is cooked and the higher the temperature to which it is submitted the less will be its nutritive and antiscorbutic value; that such deterioration in its properties is of no serious importance, if it is not forgotten, for it can be very easily remedier ; that any healthy infant can be brought up on a diet of boiled cow's milk, suitably diluted and mixed and given in proper quantities at due intervals; that failure to bring up infants on such a diet is rarely, if ever, due to the fact that the milk is cooked, but is due to some error in the mode of feeding or the amount given; that the very slight tendency to scurvy can be easily remedied by the addition of barley-water and a little fruit juice ; and, finally, that healthy boys at a public school can drink uncooked milk with impunity as long as it is not contaminated with disease germs, but that to base on such a fact an argument that infants should be fed on unboiled milk is merely a delightful instance of illogical reasoning.

Upper Brook-street, w.

\section{ON X RAYS IN THE TREATMENT OF LUPUS AND RODENT ULCER.}

\section{BY JAMES STARTIN, M.R.C.S. ENG.,} SENIOR SURGEON TO THE LONDON SKTN HOSPITAL.

IN September, 1899, I found the beneficial effects of the $\mathbf{x}$ rays in lupus, rodent ulcer, and certain other affections of the skin. I have been working with an instrument provided by Mr. Isenthal, consisting of a 15 -inch sectional coil worked at 16 volts with a mercuric interrupter. The average speed of interruptions is about 250 a minute, the average current about from three to five ampères. I used at first a five-inch tube, then a smaller one made by Cox. I place the tube generally at a distance of five inches between the anticathode and the part to be exposed, and the duration of the exposure lasts from 10 to 15 minutes, giving four or five exposures on consecutive days. In cases of lupus the skin becomes slightly red after the first four exposures, the nodules bright and shining, and the pus dries up, with no doubt destruction of the bacteria. After a few days scabs form, then drop off, leaving a red glazed surface, which may or may not scab over again. This process goes on until no more scabs are formed and the surface is smooth and normal. The surfaces acted upon become slightly odematous and a healthy epidermis begins to form. A good deal of reaction takes place in the diseased areas, such as we used to see on the administration of tuberculin a few years ago, but without any detrimental constitutional effects. This is followed by a copious discharge of serous matter which ceases in a few days.

Whether the $x$ rays operate injurionsly on the microorganisms or whether phagocytosis becomes more pronounced under the slight stimulus has not yet been definitely made out. What, then, is this curative action so destructive to bacteria and what is the agent that produces it? In what manner do the ethereal vibrations of the $x$ rays correspond to the ultra-violet, photo-chemical rays of the solar spectrum?

As far as my experience leads me at present the most suitable cases for treatment by the $x$ rays are lupus, both true and erythematous, rodent ulcer, epithelioma, psoriasis, localised eczema, lichen, alopecia areata parasitica, and other parasitic diseases of the ringworm class. To these may be added superficial cancerous affections and dermal tuberculosis. When we can get the penetrative power to extend still further, if it be true that cultivated bacteria can be destroyed in from 15 to 20 minutes, the $x$ rays show a future use in antiseptic surgery.

CASE 1. - The first case I wish to record is that of a man, aged about 60 years, who came under my notice in September, 1898 , with a large rodent ulcer extending over the whole frontal region down to the supra-orbital and nasal region, with deep ulcerations, some extending to the periosteum, and having the distinct erateriform edge characteristic of rodent ulcer. I used various treatments by caustics, ethylate of sorlium, chromic acid, salicylic collodium, powders and ointments with varied success. Nevertheless. the disease steadily ardranced, so that in June, 1900, I decided to put him under the x-rays treatment and gave him his first exposure on the 18th of that month, repeating the exposure for seven consecutive days, for 15 minutes at six inches from the skin. After the first four exposures much disturbance of tissue was noticed. The skin became red and glazed, the edges red and inflamed, and a copious discharge took place. After a day or so all discharge ceased and the sore began to take on a more healthy appearance, granulation tissue beginning to form. He went home with a simple iodoform dressing and I saw him again in July. The appearance of the wound was more healthy, but still there were two large excavated ulcers of about the size of a two-shilling piece in the centre of the area. I decided to give him a few more exposures, seven, and again in October, with the result that the raised edges of the wound became flattened, granulation tissue and an apparently healthy skin forming on most of the old sites of disease.

CASE 2.-The patient was a strong man who came under my notice three years ago with a deep foul ulcer on the forehead, nose, and face near the inner angles of both eyes, covered with thick crusts and very tender and sore, caused by a wound which he had received from the branch of a tree. I put him under various treatments by caustics, ethylate of sodium and salicylic and iodoform dressings, as in the other case, with varied results, and on Oct. 22 nd last I sent him into the hospital in Fitzroy-square and gave him 10 exposures to the $x$ rays with very beneficial results. The ulcers on the forehead and nose have nearly healed and only the ulceration in the corner of the nose and right eye remains. It is difficult to direct the rays there on account of the near proximity of the eye. The sight is unaffected at present.

In both these cases there was some considerable dermatitis, which was to be expected, and we need not be afraid of it as it promotes that disintegrative resolution in the tissues which must be present in the formation of a healthy eicatrisation. The surrounding skin has also taken on a more healthy appearance. The scars that remain are more natural and resemble the surrounding skir.

CASE 3.-A girl, aged 17 years, came under my care at the hospital in May, 1890. It was one of the worst eases of true lupus that I have seen for some years, with perforation of the bridge of the nose. I commenced treating her with tonics, quinine, and arsenic and using an antiseptic dressing of salicylic acid, iodoform, and vaseline, and on June 20th I gave her seven exposures with much the same result as in the two previous cases. There was considerable disturbance in the ulcers with much discharge for a few days. Then there followed a complete drying up of the sores and the assumption of a much more healthy appearance.

CASE 4.-A young married woman, aged about 30 years, had well-marked butterfly lupus erythematosus on both cheeks and on the bridge of the nose. The patches. which were crimson red and inflamed, were of about the size of a two-shilling piece. This patient came under my care in October, 1897. I put her under treatment of various applications, salicylic collodion, \&c., with some good results, but the case proved to be tedious, so I determined to put her under the $x$ rays at intervals of three days for a few weeks on Nov. 5th last. She has now had six applications with capital results. Cicatrisation has taken place.

CASE 5. - This patient, a young woman, aged about 21 years, came under my care at the hospital in March, 1900, with psoriasis of the legs, the arms, and the body. After reatment with tonics, arsenic, and tarry preparations she got fairly well excepting one obstinate patch about six inches 
long by three inches broad on the leg. I exposed her to the $x$ rays for seven exposures at intervals of about three days, with the result that in about a fortnight from the last exposure the whole patch completely vanished, leaving a healthy skin.

In the face of such facts it must be considered that we have in the $x$ rays a valuable therapeutic agent.

Harley-street, W.

\section{Clinital flotes:}

\section{MEDICAL, SURGICAL, OBSTETRICAL, AND THERAPEUTICAL.}

\section{A CASE OF COCAINE POISONING.}

By Kenneth Fraser, M.B., Ch.B. Aberd., JUNTOR HOUSE SURGEON, ROYAL ALBERT EDWARD INFIRMARY, WIGAX.

A WOMAN, aged 59 years, was admitted on March 11th, 1901, to the Royal Albert Edward Infirmary. Wigan, suffering from rodent ulcer situated above, and to the outer side of, the right orbit. She had been operated on about a year previously, when a portion of the frontal bone had been trephined. On the present occasion she was considered to be beyond operative treatment. On the 21st formalin (40 per cent.) was applied to the surface of the ulcer, causing great pain. On the 23rd, previously to the application of the formalin, the affected part was sprayed with 10 per cent. of cocaine. She was sprayed twice a day. On the evening of the 25th the patient became quiet, spoke in a dazed manner, and answered questions after some hesitation; she then became irritable, lying with her head buried in the pillow, and soon drifted into unconsciousness. The pulse was rapid, full, and of high pressure. The respirations became laboured, irregular, and of the Cheyne-Stokes character. Convulsive clonic spasms passed orer the whole of the body, beginning with the muscles of the mouth. Then the patient broke out into a cold perspiration and saliva ran freely from her mouth. The face was pale. The pupils were normal in size and reacted to light. There was no change in the temperature. On artificial respiration being tried the arms could not be raised above the level of the shoulders. Brandy was administered and five minims of nitrite of amyl were given and also inhalations of oxygen. Boric fomentations were applied to the affected part half-hourly. In the course of three hours the patient regained consciousness and dropped into a peaceful slumber. The following morning she felt quite well but did not remember anything of the previous night. She had received in all about five grains of cocaine. I am indebted to Mr. Berry, under whose care the case was admitted, for permission to publish these notes.

\section{MALIGNANT DLSEASE OF THE TESTICLE IN AN INFANT.}

BY H. J. ClaRK, M.R.O.S. ENG., L.R.C.P. LoND.

THE following exceptionally rare case of malignant disease of the testicle in early infant life is worthy of record.

The second child of exceptionally healthy parents was born in January, 1899. At birth the testicles had descended and no abnormal condition was observed until the child was 10 weeks old, when a slight enlargement of the left testicle was observed, without, however, any apparent cause. The enlargement in the gland increased gradually until the child was 11 months old, when it had attained to the size of a small hen's egg. There was an entire absence of swelling in the inguinal or neighbouring glands. On removal the testicle weighed 29 grammes. After operation the child did well and at present looks healthy and free from any neighbouring glandular implication.

Swanage.

Measles at Dartmouth.-At the meeting of the Dartmouth Town Council held on July 9th Mr. J. H Harris, the medical officer of health, reported that during the recent epidemic of measles 672 cases of that disease were notified. Mr. Harris added that there was an outbreak of measles in 1895, when 672 cases were also notified.

\section{A ${ }^{3}$ thirror}

OF

\author{
HOSPITAL PRACTICE, \\ BRITISH AND FOREIGN.
}

Nulla autem est alia pro certo noscendi via, nisi quamplurimas et morborum et dissectionum historias, tum aliorum tum proprias collectas habere, et inter se comparare.-Mongagni De Sed, et Caus Morb., lib. iv., Proomium.

\section{MILL ROAD INFIRMARY, LIVERPOOL.}

A CASE OF CASAREAN SECTION FOR MALIGNANT DISEASE OF THE UTERUS; RECOVERY OF MOTHER AND CHILD.

(Under the care of Dr. NATHAN RAw.)

WHEN the cervix of a pregnant uterus is discovered to be extensively affected with malignant disease and the pregnancy has reached the seventh month there can hardly be any question that the most suitable treatment is a Cæsarean section followed by complete removal of the uterus, should that be possible. The mortality at the present day from Cxsarean section is low in cases in which it is performed before the onset of labour ; but if the operation is not undertaken until labour has lasted for many hours the consequent exhaustion must necessarily exert a very harmful influence on the prognosis.

A woman, aged 30 years, was admitted into the Mill-road Infirmary, Liverpool, on May 10th, 1901, suffering from anæmia and pregnancy at the seventh month. Her father died from cancer of the stomach and her mother died from cancer of the breast. She had had seven children, of whom three were alive and well; the others died in infancy. During the last four months she had had repeated and constant hæmorrhages from the vagina, together with an offensive discharge. On admission she was pale, extremely anæmic, and very weak. The pulse was 100, small, and thready. She had lost flesh rapidly and suffered constantly from headache. On examination per vaginam there was extensive cancer of the cervix of a fungoid nature, evidently of rapid growth; it bled very readily and was pretty firmly bound down and fixed in the right fornix. The uterus was not very moveable and on examination through the speculum the cervix had a cauliflower appearance. She was evidently going rapidly downhill, as the bleeding recurred two or three times every day. The whole circumstances were explained to her husband and herself and they both agreed to the proposition of Cæsarean section.

On June 3rd she was placed under ether. Dr. Raw made an incision 10 inches long through the thin abdominal wall. The uterus was then approximated to the middle line and the abdominal cavity was shut off by large cotton sponges. The uterus was then opened by a long incision extending from the fundus to the lower segment. Unfortunately the placenta was attached right opposite the incision and Dr. Raw had rapidly to cut through it and to separate it from the uterine wall. It bled pretty freely, but the hæmorrhage was soon controlled. The membranes were then hastily opened and the child was extracted by a leg and handed to an assistant. It made no effort to breathe for at least seven or eight minutes although the heart was beating well. Finally it responded to stimulation and was soon all right. On examination of the cancerous growth from within the abdomen it was found to be too extensive to remove completely, and as the patient was very collapsed it was decided to proceed no further. The uterus was carefully sutured by 10 deep silk sutures and several superficial ones. No drain was passed through the cervix for fear of infecting the uterus from the malignant growth. The abdomen was closed without any drainage and the patient was put back to bed. She was profoundly collapsed and had to have several pints of normal saline solution per rectum as well as hypodermic injections of strychnine. She soon recovered, however, the abdominal wound healed by first intention, and she made a steady recovery and convalescence.

The child was nursed by a foster-mother for a week and was then fed in the ordinary way. The mother is gaining in weight, the hremorrhage has ceased as well as the offensive discharge, but, of course, the malignant growth is still 